PONTES, NC; FUJINAWA, MF; OLIVEIRA, JR. 2017. Selective media for detection and quantification of Brazilian Ralstonia solanacearum isolates in soil. Horticultura Brasileira 35: 041-047. DOI - http://dx.doi.org/10.1590/S0102-053620170107

\title{
Selective media for detection and quantification of Brazilian Ralstonia solanacearum isolates in soil
}

\author{
Nadson C Pontes'; Miriam F Fujinawa ${ }^{1}$; José R Oliveira ${ }^{2}$ \\ ${ }^{1}$ Instituto Federal Goiano (IFGoiano), Morrinhos-GO, Brasil; nadson.pontes@ifgoiano.edu.br; miriam.fumiko@ifgoiano.edu.br; ${ }^{2}$ Univer- \\ sidade Federal de Viçosa (UFV), Viçosa-MG, Brasil; jrogerio@ufv.br
}

\begin{abstract}
The efficacy of five selective media described in the literature for the detection of Ralstonia solanacearum in soil was evaluated using isolates from different regions of Brazil. The selective media were evaluated regarding their sensitivity, target-pathogen repression index, capacity for suppressing contaminating microorganisms and recovery rate of the pathogen in soil. No bacterial growth was observed at the concentrations tested for FSM and SM-1 media. Some isolates grew on the PCCG medium with the addition of antimicrobial agents, but only at concentrations of $10^{6} \mathrm{cfu} / \mathrm{mL}$. For the SM and SMSA-E media, adequate sensitivity for the detection of $R$. solanacearum in soil was observed, enabling detection at a concentration of approximately $10^{3} \mathrm{cfu} / \mathrm{gram}$ of soil. SMSA-E (Selective Medium South Africa Elphinstone) was found to be the most effective in suppressing the growth of contaminating microorganisms, resulting in the lowest rate of repression of $R$. solanacearum and the highest recovery rate of the bacterium in the soil.
\end{abstract}

Keywords: bacterial wilt, culture medium, diagnosis, SMSA-E.

\begin{abstract}
RESUMO
Meios seletivos para a detecção e a quantificação de isolados brasileiros de Ralstonia solanacearum no solo

Foi avaliada a eficácia de cinco meios seletivos descritos na literatura para a detecção de Ralstonia solanacearum no solo, utilizando-se isolados provenientes de diferentes regiões do Brasil. Os meios seletivos foram avaliados quanto à sensibilidade, índice de repressão ao patógeno alvo, capacidade de supressão de microrganismos contaminantes e taxa de recuperação da bactéria no solo. Não foi possível observar crescimento bacteriano nas concentrações avaliadas para os meios FSM e SM-1. Alguns isolados cresceram no meio PCCG com adição dos agentes microbianos, mas apenas na concentração de $10^{6}$ ufc/mL. Para os meios SM e SMSA-E, observou-se sensibilidade adequada para detecção de $R$. solanacearum no solo, possibilitando detectar a bactéria em concentrações próximas de $10^{3} \mathrm{ufc} /$ grama de solo. O meio SMSA-E (Selective Medium South Africa - Elphinstone) foi o mais eficaz em suprimir o desenvolvimento de microrganismos contaminantes, apresentando o menor índice de repressão à $R$. solanacearum e a maior taxa de recuperação da bactéria no solo.
\end{abstract}

Palavras-chave: murcha bacteriana, meio de cultura, diagnose, SMSA-E.

Received on June 23, 2015; accepted on May 25, 2016

$R^{a}$ alstonia solanacearum is the causal agent of bacterial wilt in several hundreds of plant species. Many vegetables are host of this pathogen, especially members of the family Solanaceae, such as tomato, potato, eggplant, pepper, tobacco and chilli (Lebeau et al., 2011). For many years, pathogenic races (five) and biovars (six) represented the variability of this pathogen (Morais et al., 2015). This approach, although old and artificial, is still used in almost all articles. In Brazil, filotype I, which corresponds to biovar 3 , and filotype II, the most prevalent, are found (Morais et al., 2015).

Currently, $R$. solanacearum is considered a complex species with extensive genetic diversity, which can be divided into four phylotypes: I- isolates from Asia, IIA and IIB- Americas, IIIAfrica, and IV- Indonesia (Genin \& Denny, 2012). In a study carried out by Santiago (2014), including 120 isolates from 19 Brazilian states and 12 host species, the presence of biovars 1,2 and 3 , and phylotypes I and II was detected, the latter corresponding to $95.8 \%$ of the isolates.

Since it is a pathogen very well adapted to soil (Brown, 2009), field research aiming at studying the population dynamics of $R$. solanacearum in soil rely on available techniques able to detect and quantify the bacterium in this environment. Indirect methods, such as bioassays for the detection of bacteria in soil were the first used for this purpose. However, there is some resistance to employing them because they require a considerable amount of time and environmental controlled conditions (Pradhanang et al., 2000; Tavares et al., 2000), besides being most sensitive enough.

Polymerase chain reaction (PCR) shows great potential because it is a sensitive and specific molecular technique for the detection and quantification of $R$. solanacearum in soil (Pradhanang et al., 2000; Inoue \& Nakaho, 2014). However, the significant cost of this technique (equipment and reagents), coupled with the lack of appropriate structure in some research institutions, restrict its use, and this method is therefore mainly performed to calibrate less expensive techniques (Van Der Wolf et al., 2000; Ha et al., 2012; Martinelli et al., 2014). 
The use of serological methods has also been evaluated as a means of detecting $R$. solanacearum in soil (Pradhanang et al., 2000; Priou et al., 2006; Arslan et al., 2014). These methods, such as ELISA, are useful in the evaluation of large numbers of samples, because they are relatively inexpensive and easy to perform. However, these techniques are only effective when the bacterial population exceeds $10^{4} \mathrm{cfu} / \mathrm{g}$ soil.

The use of a selective medium is a direct method commonly used for the detection of bacteria in soil. This method consists of plating the diluted soil extracts on medium where contaminants (non-desirable organisms) cannot develop or develop at a slow pace, favoring the growth of the desired organism for identification and quantification purposes (Priou et al., 2006).

The high acceptability of selective media may be a reflection of its practicality, sensitivity and specificity, associated with its relative low cost and accurate quantification of culturable populations in soil (Pradhanang et $a l ., 2000)$. Moreover, it is the only method able to provide colonies of the bacterium. This is important to detect alive cells of phytopathogenic bacteria, a requirement in the legislation of many countries to confirm the presence of the pathogen. Thus, selective media can complement the results obtained by molecular and/or serological techniques, which make no distinction between alive or dead cells.

The major constrain to the use of selective media is that they exhibit variable efficacy, being effective just for the isolates used during its elaboration (Priou et al., 2006). Therefore, the present study aimed to evaluate the efficacy of five selective media reported in the literature for the detection and quantification of $R$. solanacearum in soil using isolates from different Brazilian regions.

\section{MATERIAL AND METHODS}

Ralstonia solanacearum isolates (Table 1) were acquired through sampling and donations, originating from different parts of Brazil. These isolates were inoculated onto tomato plants cv. Santa Clara (21-day old) and subsequently re-isolated to eliminate differences in age and to determine their virulence. The method used for the inoculation of plants was root immersion in a bacterial suspension containing approximately $10^{8} \mathrm{cfu} / \mathrm{mL}$ (Pontes et al., 2011). After determination of wilt symptoms in such plants, the bacterium was re-isolated, and the isolates were stored in tubes containing sterile water and cryopreserved in $40 \%$ glycerol at $-80^{\circ} \mathrm{C}$.

To prepare the inoculum, the isolates were streaked on CPG (Casamino acid, Peptone, Glucose) medium (Kelman, 1954) and incubated at $28 \pm 1^{\circ} \mathrm{C}$ for 48 hours. After this period, the cells were suspended in a sterile saline solution $(0.85 \% \mathrm{NaCl})$, and the turbidity of the suspension was adjusted to $\mathrm{OD}_{600}=0.1$ in a spectrophotometer (Spectronic $20^{\circledR}$ ). This initial suspension was diluted depending on the desired concentration for analysis.

The following media were evaluated: Selective Medium [SM (Karganilla \& Buddenhagen, 1972)], Final Selective Medium [FSM (Nesmith \& Jenkins, 1979)], Selective Medium 1 [SM-1 (Granada \& Sequeira, 1983)], Potato Crystal violet Chloramphenicol Gellan gum [PCCG (Hara et al., 1995)] and Selective Medium South Africa Elphinstone [SMSA-E (Elphinstone et al., 1996)]. All media were prepared according to the protocols described in the original studies (Table 2). After addition of the media to Petri dishes $(90 \mathrm{~mm}$ diameter by $15 \mathrm{~mm}$ height), the dishes were subdivided externally into six sections, and each of these was planted with $10 \mu \mathrm{L}$ of a bacterial suspension from a specific isolate with the aid of a calibrated polystyrene inoculating loop. Each isolate was planted from suspensions at concentrations of $1 \times 10^{6}, 1 \times 10^{4}$ and $1 \times 10^{2}$ $\mathrm{cfu} / \mathrm{mL}$. The plates were maintained at $28 \pm 1^{\circ} \mathrm{C}$ and, after 96 hours, the presence of bacterial growth on plates containing selective media was assessed. Triphenyl Tetrazolium Chloride (TTC) medium (Kelman, 1954) was adopted as the standard medium for the cultivation of the isolates. The growth of isolates on selective medium without the addition of antimicrobial agents was also assessed.

To determine the repression index (RI) of the selective media, an isolate of $R$. solanacearum, which grew on most of the tested media was chosen. A culture of this isolate was incubated for 72 hours at $28 \pm 1^{\circ} \mathrm{C}$ and then suspended in sterile saline solution $(0.85 \%)$ supplemented with $0.5 \%$ Tween 80 . The suspension was adjusted to concentrations of $1 \times 10^{4}$, $1 \times 10^{3}$ and $1 \times 10^{2} \mathrm{cfu} / \mathrm{mL}$ using the same saline solution. A $50 \mu \mathrm{L}$ aliquot of each concentration was placed in Petri dishes containing the various media and spread with the aid of a Drigalsky loop. The plates were then maintained at $28 \pm 1^{\circ} \mathrm{C}$. The number of bacterial colonies on each plate was counted after 24,48 and 72 hours. To calculate the RI (\%), the difference between the number of colonies observed on each selective medium and on the TTC standard was divided by the number of colonies on the TTC medium, and the obtained value multiplied by 100 . Only the media that enabled the growth of all isolates were used.

To determine the suppression index (SI) for the selective media in relation to contaminating microorganisms present in the soil, a sample of 10 grams of sieved soil ( $2 \mathrm{~mm}$ mesh) was suspended in $100 \mathrm{~mL}$ of sterile saline solution supplemented with $0.5 \%$ Tween 80 , followed by stirring at $150 \mathrm{rpm}$ for 30 minutes. This soil sample, from a typical red yellow latosol with clay texture, was obtained from a field cultivated with tomatoes and other vegetables. A $10^{-1}$ to $10^{-5}$ dilution series was obtained for the suspension, also in sterile saline solution containing Tween 80 . A $10 \mu \mathrm{L}$ aliquot of each dilution was placed on Petri dishes containing the different media. These aliquots were deposited and spread with the aid of a $10 \mu \mathrm{L}$ calibrated loop. The plates were incubated at $28 \pm 1^{\circ} \mathrm{C}$ and after 24, 48 and 72 hours, when the growth of contaminating bacteria was assessed. To determine the SI values (\%) for each selective medium, the difference between the number of cfu/ $\mathrm{mL}$ of contaminating microorganisms determined by counts on the TTC standard medium and on the selective 
medium was divided by the total $\mathrm{cfu} / \mathrm{mL}$ on the TTC medium, and the obtained value was multiplied by 100 . Only the media that enabled the growth of all isolates were used.

To determine the recovery rate ( $\mathrm{RR}$ ) and determine the selective medium sensibility, nine grams of sieved soil ( $2 \mathrm{~mm}$ mesh) from a field cultivated with tomatoes and other vegetables was placed in $250 \mathrm{~mL}$ Erlenmeyer flasks. The soil samples were seeded with 1 $\mathrm{mL}$ of a $R$. solanacearum suspension prepared using an isolate that was able to grow on most media, adjusted to concentrations of $1 \times 10^{8}, 1 \times 10^{6}$ and $1 \times 10^{4} \mathrm{cfu} / \mathrm{mL}$, with the final mixtures corresponding to approximately $1 \times 10^{7}$, $1 \times 10^{5}$ and $1 \times 10^{3} \mathrm{cfu} / \mathrm{g}$ soil, respectively. After 30 minutes, sterile saline solution containing Tween 80 was added to achieve a total volume of $100 \mathrm{~mL}$. The suspension was stirred at $150 \mathrm{rpm}$ for 30 minutes, and serial dilutions of $10^{-1}$ to $10^{-5}$ were performed, also in sterile saline containing Tween 80 . A $100 \mu \mathrm{L}$ aliquot of each dilution was deposited on plates containing the various selective media. This aliquot was spread with the aid of a Drigalsky loop. The plates were then incubated at $28 \pm 1^{\circ} \mathrm{C}$ and the number of colonies on the selective media was determined after 24, 48 and 72 hours of incubation. The recovery rate (RR) of each medium was determined by dividing the number of $\mathrm{cfu} / \mathrm{g}$ soil estimated using the selective medium by the total number added to the soil and then multiplying the result by 100 . Only the media that enabled the growth of all isolates were used.

All experiments were conducted in a completely randomized design with four replicates for each treatment. The analyses were performed using a factorial design. The effects of the factors and the interactions among them were assessed using an F-test $(p \leq 0.05)$ of analysis of variance and, when significant, the means were compared based on the confidence interval (alpha $=0.05)$. The statistical analyses were performed using the GLM procedure of the SAS 9.1 statistical software (Statistical Analysis System, SAS Institute Inc., Cary, NC).

\section{RESULTS AND DISCUSSION}

All isolates of R. solanacearum grew on the TTC medium and on the media devoid of antimicrobial agents. In the presence of antimicrobial agents, only the SM and SMSA-E media enabled the growth of all isolates at concentrations of $10^{6}, 10^{4}$ and $10^{2} \mathrm{cfu} / \mathrm{mL}$. Some isolates grew on the PCCG medium with the addition of antimicrobial agents, but only at concentrations of $10^{6}$ (UFV 12 , UFV 13, UFV 14, and UFV 17) and $10^{4}$ $\mathrm{cfu} / \mathrm{mL}$ (UFV 12, UFV 13, and UFV 14). There was no bacterial growth in FSM and SM-1 media with the addition of antimicrobial agents.

The emergence of the first colonies on the selective media with antimicrobial agents was observed 24 hours after plating. The colonies cultured on the SM and SMSA-E media exhibited a white color or were white with a reddish center. On the latter medium, the colonies displayed a mucoid appearance with irregular edges, similar to that observed on the TTC medium (Kelman, 1954). On the SM medium, the colonies were smaller compared with those in the standard medium and exhibited more regular edges. The colonies on the SM medium were also clearly smaller compared with those on the SMSA-E medium. Since all isolates grew on the SM and SMSA-E media with and without antimicrobial agents, the UFV 1 isolate was chosen for determining the repression index (RI) and the recovery rate (RR) of the bacterium in soil.

For the RI, no interaction was observed between the factors 'media' and 'bacterial concentration' ( $F$, $\mathrm{p}=0.895$ ). The SMSA-E selective medium showed low levels of repression at all tested concentrations (Table 3 ), in contrast to the values observed using the SM selective medium, which showed a high RI value, completely repressing the growth of $R$. solanacearum at concentrations around $10^{2} \mathrm{cfu} / \mathrm{mL}$ in some replicates. The maximum number of colonies was obtained after 48 hours of incubation, with no increase in this value observed after 72 hours of incubation in both medium. There was no effect of the inoculum concentration

Table 1. Ralstonia solanacearum isolates used in the evaluation of different selective media. Viçosa, UFV, 2016.

\begin{tabular}{lllc}
\hline $\begin{array}{l}\text { Code of } \\
\text { the isolate }\end{array}$ & Origin of the isolate & Host & Biovar \\
\hline UFV 1 & Ervália-MG & Tomato & 1 \\
UFV 2 & Coimbra-MG & Tomato & 1 \\
UFV 3 & Cruz das Almas-BA & Tomato & ND \\
UFV 4 & Cruz das Almas-BA & Eggplant & ND \\
UFV 5 & Rio de Janeiro-RJ & Tomato & ND \\
UFV 6 & Brasília-DF & Tomato & 3 \\
UFV 7 & Monte Dourado-PA & Eucalyptus & 1 \\
UFV 8 & São Luís-MA & Tomato & ND \\
UFV 9 & Venda Nova do Imigrante-ES & Tomato & 1 \\
UFV 10 & Ceres-GO & Tomato & 1 \\
UFV 11 & Canguçu-RS & Tomato & 2 \\
UFV 12 & Manaus-AM & Tomato & 3 \\
UFV 13 & Camocim de São Félix-PE & Tomato & 3 \\
UFV 14 & Porto Velho-RO & Tomato & 1 \\
UFV 15 & Sumaré-SP & Tomato & 1 \\
UFV 16 & Boa vista-RR & Bell pepper & 1 \\
UFV 17 & USA (Type Strain, = ICMP 1727; & Tomato & 1 \\
\hline
\end{tabular}

ND: not determined. 
Table 2. Composition of selective media with the quantities of each component (per liter). Viçosa, UFV, 2016.

\begin{tabular}{|c|c|}
\hline FSM (Nesmith \& Jer & SM (Karganilla \& Buddenhagen, 1972) \\
\hline $\begin{array}{l}\text { Agar } 20 \mathrm{~g} \\
\left(\mathrm{NH}_{4}\right)_{2} \mathrm{SO}_{4} 1.32 \mathrm{~g} \\
\text { Casein hydrolysate } 1 \mathrm{~g} \\
\text { Citric acid } 1.9 \mathrm{mg} \\
\mathrm{FeC}_{6} \mathrm{H}_{5} \mathrm{O}_{7} .5 \mathrm{H}_{2} \mathrm{O} 3 \mathrm{mg} \\
\mathrm{Glucose}^{\mathrm{g}} \mathrm{g} \\
\mathrm{K}_{2} \mathrm{HPO}_{4} 1.18 \mathrm{~g} \\
\mathrm{KH}_{2} \mathrm{PO}_{4} 0.44 \mathrm{~g} \\
\mathrm{MgSO}_{4} \cdot 7 \mathrm{H}_{2} \mathrm{O} 0.2 \mathrm{~g} \\
\mathrm{MnSO}_{4} \cdot \mathrm{H}_{2} \mathrm{O} 1.5 \mathrm{mg} \\
\text { Peptone } 10 \mathrm{~g} \\
\mathrm{Yeast} \mathrm{extract} 1 \mathrm{~g} \\
\text { ZnSO } \\
{ }^{1} \cdot 7 \mathrm{H}_{2} \mathrm{O} 1.6 \mathrm{mg} \\
\text { Bacitracin } 50 \mathrm{mg} \\
\text { Benomyl } 500 \mathrm{mg} \\
\text { Chloramphenicol } 5 \mathrm{mg} \\
\text { Chloroneb } 100 \mathrm{mg} \\
\text { Cycloheximide } 50 \mathrm{mg} \\
\text { Dichloran } 100 \mathrm{mg} \\
\text { Penicillin } \mathrm{G} 1 \mathrm{mg} \\
\text { Pimaricin } 20 \mathrm{mg} \\
\text { Polymyxin sulfate } 100 \mathrm{mg} \\
\text { Quintozene } 30 \mathrm{mg} \\
\text { Triphenyl tetrazolium chloride } 500 \mathrm{mg} \\
\text { Tyrothricin } 20 \mathrm{mg} \\
\text { Vancomycin } 10 \mathrm{mg}\end{array}$ & $\begin{array}{l}\text { Agar } 20 \mathrm{~g} \\
\text { Glutamic acid } 1 \mathrm{~g} \\
\text { Mannitol } 2.5 \mathrm{~g} \\
\mathrm{MgSO}_{4} \cdot 7 \mathrm{H}_{2} \mathrm{O} 1.6 \mathrm{~g} \\
\text { Stock solution of metals } 0.5 \mathrm{~mL} \text { : } \\
\quad \mathrm{MnSO}_{4} \cdot \mathrm{H}_{2} \mathrm{O} 616 \mathrm{mg} / 100 \mathrm{~mL} \\
\quad \mathrm{ZnSO}_{4} \cdot 7 \mathrm{H}_{2} \mathrm{O} 1.1 \mathrm{~g} / 100 \mathrm{~mL} \\
\quad \mathrm{FeSO}_{4}\left(\mathrm{NH}_{2}\right)_{2} \mathrm{SO}_{4} \cdot 6 \mathrm{H}_{2} \mathrm{O} 176 \mathrm{mg} \\
\quad \mathrm{CoSO}_{4} \cdot 5 \mathrm{H}_{2} \mathrm{O} 28 \mathrm{mg} / 100 \mathrm{~mL} \\
\quad \mathrm{CuSO}_{4} \cdot 5 \mathrm{H}_{2} \mathrm{O} 28 \mathrm{mg} / 100 \mathrm{~mL} \\
\quad \mathrm{H}_{3} \mathrm{BO}_{3} 11.44 \mathrm{mg} / 100 \mathrm{~mL} \\
\mathrm{KI}_{0.0128 \mathrm{mg} / 100 \mathrm{~mL}} \\
\quad \mathrm{~K}_{2} \mathrm{HPO}_{4}(0.0002 \mathrm{M}) 1 \mathrm{~mL} \\
\quad \mathrm{KH}_{2} \mathrm{PO}_{4}(0.0002 \mathrm{M}) 1 \mathrm{~mL} \\
\text { Adjust pH for } 7.2 \text { and add: } \\
\text { Bacitracin } 500 \mathrm{mg} \\
\text { Captan } 10 \mathrm{mg} \\
\text { Chloramphenicol } 5 \mathrm{mg} \\
\text { Cycloheximide } 50 \mathrm{mg} \\
\text { Penicillin } \mathrm{G} 1 \mathrm{mg} \\
\text { Triphenyl tetrazolium chloride } 500 \mathrm{mg} \\
\text { Tyrothricin } 20 \mathrm{mg} \\
\text { Vancomycin } 10 \mathrm{mg}\end{array}$ \\
\hline SMSA-E (French et al., 1995) & PCCG (Hara et al., 1995) \\
\hline $\begin{array}{l}\text { Agar } 15 \mathrm{~g} \\
\text { Casein hydrolysate } 1 \mathrm{~g} \\
\text { Glycerol } 5 \mathrm{~mL} \\
\text { Peptone } 10 \mathrm{~g} \\
\end{array}$ & $\begin{array}{l}\text { Agar } 15 \mathrm{~g} \\
\mathrm{Ca}\left(\mathrm{NO}_{3}\right)_{2} \cdot 4 \mathrm{H}_{2} \mathrm{O} 0.5 \mathrm{~g} \\
\mathrm{Glucose} 15 \mathrm{~g} \\
\mathrm{Na}_{2} \mathrm{HPO}_{4} \cdot 12 \mathrm{H}_{2} \mathrm{O} 2 \mathrm{~g}\end{array}$ \\
\hline $\begin{array}{l}\text { Bacitracin } 25 \mathrm{mg} \\
\text { Chloramphenicol } 5 \mathrm{mg} \\
\text { Crystal violet } 5 \mathrm{mg} \\
\text { Cycloheximide } 100 \mathrm{mg} \\
\text { Penicillin G } 0.5 \mathrm{mg} \\
\text { Polymyxin sulfate } 100 \mathrm{mg} \\
\text { Triphenyl tetrazolium chloride } 50 \mathrm{mg}\end{array}$ & $\begin{array}{l}\text { Peptone } 5 \mathrm{~g} \\
\text { Potato broth } 300 \mathrm{~g} / \mathrm{L} \\
\text { Chloramphenicol } 7.5 \mathrm{mg} \\
\text { Crystal violet } 5 \mathrm{mg} \\
\text { Cycloheximide } 50 \mathrm{mg} \\
\text { Polymyxin sulfate } 4 \times 10^{5} \mathrm{UI} \\
\text { Triphenyl tetrazolium chloride } 25 \mathrm{mg}\end{array}$ \\
\hline SM-1 (Granada \& Sequeira, 1983) & TTC medium (Kelman, 1954) \\
\hline $\begin{array}{l}\text { TTC medium } \\
\text { Chloramphenicol } 5 \mathrm{mg} \\
\text { Chlorothalonil } 80 \mathrm{mg} \\
\text { Crystal violet } 50 \mathrm{mg} \\
\text { Cycloheximide } 50 \mathrm{mg} \\
\text { Polymyxin sulfate } 100 \mathrm{mg} \\
\text { Thimerosal } 5 \mathrm{mg} \\
\text { Triphenyl tetrazolium clhoride } 50 \mathrm{mg} \\
\text { Tyrothricin } 20 \mathrm{mg}\end{array}$ & $\begin{array}{l}\text { Agar } 16 \mathrm{~g} \\
\text { Casein hydrolysate } 1 \mathrm{~g} \\
\text { Glucose } 5 \mathrm{~g} \\
\text { Peptone } 10 \mathrm{~g} \\
\text { Triphenyl tetrazolium chloride } 50 \mathrm{mg}\end{array}$ \\
\hline
\end{tabular}

${ }^{1}$ Antimicrobials and triphenyl tetrazolium chloride were added after autoclaving (30 min at $120^{\circ} \mathrm{C}$ ). on the RI values ( $\mathrm{F}, \mathrm{p}=0.893)$.

When the results for the SI were evaluated (Table 4), there was an interaction observed between the factors 'incubation time' and 'selective medium' ( $F, p=0.0008)$. At incubation times of 24 and 48 hours, no differences were found between the media concerning the suppression of contaminating microorganisms. After 72 hours of incubation, the SMSA-E medium showed a small reduction in the SI compared with the values observed in this medium at 24 and 48 hours and compared with the SM medium. This small reduction in the suppression index was sufficient for several colonies to be observed (approximately $2.3 \mathrm{cfu} / \mu \mathrm{L}$ of soil suspension), which might interfere with the colony counts of the target organism at low concentrations. The SM medium did not exhibit variation in the SI, with high values being obtained at all tested concentrations.

The data analysis considered the counts of the number of colonies after 48 hours of incubation because, in the experiment to determine (RI), the maximum number of $R$. solanacearum colonies was obtained at this time, without increase in this value being observed after 72 hours of incubation. In addition, longer periods of incubation resulted in a higher number of contaminating organisms, becoming it difficult to count the $R$. solanacearum colonies.

There was an effect of the evaluated factors on the RR of the bacterium in the soil, although no significant interaction was found among them ( $F, p=0.773)$. At the highest concentration of the bacterium in the soil $\left(1 \times 10^{7} \mathrm{cfu} / \mathrm{g}\right.$ soil $)$, the RR was two times higher than the rates observed for treatments with lower concentrations (Table 5). The SMSA-E medium showed a higher recovery rate of the bacterium compared with the SM medium. However, the values observed for this variable can be considered low, reaching slightly more than $50 \%$ in the presence of a high concentration of the pathogen in soil. This is an indication of a low sensitivity of the medium.

As the base compositions of all studied selective media allowed the growth of $R$. solanacearum isolates, 
the inhibition of the development of colonies of this bacterium by some of these media can be attributed to the substances added to them, whether these substances were antimicrobial or not. For example, triphenyl tetrazolium chloride aids in the identification of virulent $R$. solanacearum colonies, but at concentrations above $500 \mathrm{mg} / \mathrm{L}$, it can inhibit the growth of this bacterial species (Nesmith \& Jenkins, 1979). This may have contributed to the inhibition of the isolates evaluated on the FSM medium, which contains the highest concentration of this salt among the evaluated media.

Another important aspect is that the FSM medium was prepared on the basis of testing only one $R$. solanacearum isolate, originating from North Carolina (USA). When this medium was evaluated for isolates from other regions, many of them, including some from Colombia, were totally inhibited, and those that were not inhibited grew only when plated at inoculum concentrations above $10^{5} \mathrm{cfu} / \mathrm{mL}$ (Nesmith \& Jenkins, 1979).

The SM-1 medium differs from other selective media studied mainly for containing the antimicrobial agent thimerosal. Granada \& Sequeira (1983) observed that $R$. solanacearum isolates from Japan were sensitive to thimerosal. In addition, these authors recorded a relatively high repression rate (approximately 80\%) depending on the isolates involved, particularly for races 2 and 3, when using the SM-1 medium.

All of the media studied herein contain the antibiotic chloramphenicol, with the highest concentration (7.5 $\mathrm{mg} / \mathrm{L}$ ) being found in the PCCG medium. According to Granada \& Sequeira, (1983) and Romeiro et al. (1998), several $R$. solanacearum isolates are sensitive to this antibiotic. Thus, a higher chloramphenicol concentration may inhibit the growth of some isolates. It is worth noting that inhibition of the development of a microorganism is not always solely due to the action of a single antimicrobial agent and that a combination of substances to which the bacterium is otherwise insensitive could also inhibit its development.

Although all isolates were able to grow on it, the $R$. solanacearum colonies

Table 3. Repression indices (\%) when using the SM and SMSA-E selective media for the Ralstonia solanacearum UFV 1 isolate after 72 hours of incubation. Viçosa, UFV, 2016.

\begin{tabular}{lccc}
\hline \multirow{2}{*}{ Inoculum (cfu/mL) } & \multicolumn{2}{c}{ Repression indices (\%) } & \multirow{2}{*}{ Mean (\%) ${ }^{\mathbf{N S}}$} \\
\cline { 2 - 3 } & SM & SMSA-E & \\
\hline $10^{4}$ & 92.57 & 0.63 & $46.6 \pm 15.7$ \\
$10^{3}$ & 92.10 & 14.68 & $53.3 \pm 13.4$ \\
$10^{2}$ & 99.99 & 0.00 & $49.9 \pm 16.9$ \\
\hline Mean (\%) & $94,8 \pm 2,3$ & $5,1 \pm 2,9$ & \\
\hline
\end{tabular}

"Significant and ${ }^{\mathrm{NS}}$ non-significant $(\mathrm{F}, \mathrm{p} \leq 0.05) . \pm$ Confidence interval (alpha $=0.05$ ).

Table 4. Suppression indices (\%) obtained for the SM and SMSA-E selective media for microorganisms present in the soil after different incubation times. Viçosa, UFV, 2016.

\begin{tabular}{lcc}
\hline \multirow{2}{*}{ Incubation time (hours) } & \multicolumn{2}{c}{ Suppression indices (\%)* } \\
\cline { 2 - 3 } & SM & SMSA-E \\
\hline 24 hours & $100 \pm 0.0$ & $100 \pm 0.0$ \\
48 hours & $100 \pm 0.0$ & $99.97 \pm 0.05$ \\
72 hours & $99.98 \pm 0.02$ & $99.77 \pm 0.08$ \\
\hline
\end{tabular}

*Values corresponding to average of all dilutions, which was considered when the number of colony-forming units was between 300 and $3 . \pm$ Confidence interval (alpha $=0.05$ ).

Table 5. Recovery rate (\%) of Ralstonia solanacearum isolate (UFV 1) from soil infested with different bacterial concentrations when using the SM and SMSA-E selective media. Viçosa, UFV, 2015.

\begin{tabular}{|c|c|c|c|c|}
\hline \multirow[b]{2}{*}{ Selective media } & \multicolumn{3}{|c|}{ Recovery rate $(\%)$} & \multirow{2}{*}{$\begin{array}{c}\text { Mean } \\
(\%)^{*}\end{array}$} \\
\hline & $\begin{array}{c}10^{7} \\
\text { (cfu/g soil) }\end{array}$ & $\begin{array}{c}10^{5} \\
\text { (cfu/g soil) }\end{array}$ & $\begin{array}{c}10^{3} \\
\text { (cfu/g soil) }\end{array}$ & \\
\hline SMSA-E & 51.93 & 29.29 & 40.44 & $40.5 \pm 4.9$ \\
\hline SM & 32.97 & 7.15 & 2.13 & $14.1 \pm 4.6$ \\
\hline Mean $(\%)^{*}$ & $42.4 \pm 3.5$ & $18.2 \pm 11.2$ & $21.2 \pm 4.8$ & \\
\hline
\end{tabular}

*Significant (F, $\mathrm{p} \leq 0.05) . \pm$ Confidence interval (alpha $=0.05)$.

observed on SM medium were smaller and less fluid than those grown on TTC medium, which was also observed by Karganilla \& Buddenhagen (1972) and Nesmith \& Jenkins (1979). Nesmith \& Jenkins (1979) attributed this finding to the combination of antimicrobial agents, because the addition of these agents to the TTC medium gave rise to colonies with similar characteristics. This effect may interfere with the differentiation between virulent and avirulent $R$. solanacearum colonies as well as contaminant bacteria.

The repression index observed for the SM medium was much higher than the $37 \%$ rate obtained by Karganilla \& Buddenhagen (1972), possibly because the medium was prepared by testing only one $R$. solanacearum isolate. Several authors have described the SM medium as appropriate only for certain isolates and as being of low efficacy in the detection of $R$. solanacearum (Nesmith \& Jenkins, 1979; Granada \& Sequeira, 1983; Moura \& Romeiro, 1998). Another important aspect of this medium is that the use of mannitol as a carbon source makes it suitable only for isolates of biovars 3 and 4, which are able to grow when mannitol is the only carbon source. Thus, isolates from other biovars, may not develop on the SM medium. Taking into consideration that the preparation of the medium involves autoclaving of all components, it is likely that this process can cleave small amounts of sugar, which would enable the growth of isolates belonging to other biovars.

The base composition of the SM medium is very different from those 
of the other selective media evaluated because it was developed to meet the nutritional needs of $R$. solanacearum and to restrict contaminating organisms. However, with the increased availability of genetic information on this bacterium and, thus, its nutritional requirements, it is possible to develop media that are more restrictive while still enabling good development of the target microorganism (Kawanishi et al., 2011).

The SMSA-E medium exhibits a base composition that is similar to that of the TTC medium, which is most likely the reason for that the colonies that develop on these two media show a similar appearance. Elphinstone et al. (1996) and Pradhanang et al. (2000) also reported similar characteristics between the colonies that formed on the SMSA-E and TTC media. The characteristics of the colonies on these two media allow the differentiation of $R$. solanacearum from possible contaminants. The SMSA-E medium exhibits the lowest number and the lowest concentrations of antimicrobial agents among the evaluated media, thus reducing its potential for inhibition of the target bacterium.

The antibiotic present at the highest concentration in the SMSA-E medium is polymyxin $\mathrm{B}$, to which $R$. solanacearum shows constitutive resistance (Romeiro et al., 1998). The addition of this antibiotic is advised in the preparation of any selective medium for this bacterium because it improves in the inhibition of other Gram-negative bacteria that are present in soil (Kurylowicz, 1981).

Both the SM and SMSA-E media are described as being effective in inhibiting the growth of contaminating microorganisms in soil (Karganilla \& Buddenhagen, 1972; Elphinstone et al., 1996; Pradhanang et al., 2000), showing suppression rates above $80 \%$. Even when it is not possible to completely eliminate these microorganisms, the few days for which their development is inhibited may be sufficient for the detection and quantification of the target microorganism.

The main factor contributing to good recovery of the target bacteria from soil is the efficacy of the applied extraction method (Pradhanang et al., 2000), especially when using media with a low RI and high SI, as observed for the SMSA-E medium. Several extraction methods for $R$. solanacearum in soil can be found in the literature (Moura \& Romeiro, 1998; Pradhanang et al., 2000, 2003).

Among the selective media evaluated in this work, the SMSA-E medium is the most frequently cited in epidemiological studies, being considered an effective tool for assessing the $R$. solanacearum population in soil. This medium has been used effectively in studies involving bacterial isolates races 1 and 3 and several biovars from Spain, Italy, UK, South Africa, Nepal, USA and the Netherlands (Elphinstone et al., 1996; Pradhanang et al., 2000, 2003; Van Der Wolf et al., 2000; Caruso et al., 2005; Di Bisceglie et al., 2005; Priou et al., 2010).

The repression index exhibited by the SMSA-E medium was lower than that reported for the selective medium developed by Moura \& Romeiro (1998) for Brazilian $R$. solanacearum isolates. In the study conducted by these authors, the prepared medium allowed the growth of a large number of isolates, although repression rates above $75 \%$ were observed depending on the dilution.

Other techniques, such as methods based on PCR, are more precise and sensitive than the use of selective media. PCR can therefore, be used to increase the detectability of the bacterium in association with selective media. For example, in BIO-PCR (Lin et al., 2009), the enrichment of the sample with selective medium significantly increases the number of target cells and reduces the relative concentration of PCR inhibitors (Ha et al., 2012). This method of sample enrichment using selective media has also proven effective when associated with serological techniques (Priou et al., 2010). Further considering the possibility of exclusively detecting and quantifying culturable cells, selective media that allow the development of $R$. solanacearum and suppress contaminants represent useful tools for studying the dynamics of this bacterium in substrates as complex as soil and water samples.

Although it is necessary to evaluate a large number of isolates from other regions in Brazil, the fact that the SMSA-E medium is used efficiently in different locations around the world and shows satisfactory results for the isolates used in the present study demonstrates its potential for application in studies on $R$. solanacearum populations in Brazil.

\section{ACKNOWLEDGEMENTS}

The first and second authors express their gratitude to Fundação de Amparo à Pesquisa do Estado de Minas Gerais (FAPEMIG) and Conselho Nacional de Desenvolvimento Científico e Tecnológico (CNPq) for their M.Sc. fellowships, respectively. The authors are very grateful to Carlos Alberto Lopes, Centro Nacional de Pesquisa de Hortaliças and Júlio Rodrigues Neto, Instituto Biológico, for the donation of isolates.

\section{REFERENCES}

ARSLAN, S; BARTIN, M; KILINÇ, AO; KAFADAR, FN; CAN, C. 2014. Comparison of specificity and sensitivity of newly developed techniques for routine detection of Ralstonia solanacearum (race-2) in soil. In: INTERNATIONAL CONFERENCE ON ENVIRONMENTAL SCIENCE AND TECHNOLOG. Anais... Side: Journal of Selçuk University Natural and Applied Science. p. 567-575.

BROWN, D. 2009. Ralstonia solanacearum and bacterial wilt in the post-genomic era. In: JACKSON, RW (ed). Plant pathogenic bacteria: genomics and molecular biology. Norfolk: Caister Academic Press. p.175-202.

CARUSO, P; PALOMO, JL; BERTOLINI, E; ALVAREZ, B; LOPEZ, MA; BIOSCA, EG. 2005. Seasonal variation of Ralstonia solanacearum biovar 2 populations in a Spanish river: recovery of stressed cells at low temperatures. Applied and Environmental Microbiology 71: 140-148.

DI BISCEGLIE, DP; SACCARDI, A; GIOSUE, S; TRAVERSA, F; MAZZUCCHI, U. 2005. Survival of Ralstonia solanacearum on wood, high density polyethylene and on jute fabric in cold storage. Journal of Plant Pathology 87: 145-147.

ELPHINSTONE, JG; HENNESSY, J; WILSON, JK; STEAD, DE. 1996. Sensitivity of different methods for the detection of Ralstonia solanacearum in potato tuber extracts. EPPO Bulletin 26: 663-678.

GENIN, S; DENNY, TP. 2012. Pathogenomics of the Ralstonia solanacearum species complex. Annual Review of Phytopathology 50: 67-89.

GRANADA, GA; SEQUEIRA, L. 1983. A 
new selective medium for Pseudomonas solanacearum. Plant Disease 67: 1084-1088.

HA, Y; KIM, JS; DENNY, TP; SCHELL, MA. 2012. A rapid, sensitive assay for Ralstonia solanacearum race 3 biovar 2 in plant and soil samples using magnetic beads and real-time PCR. Plant Disease 96: 258-264.

HARA, H; KOGA, K; TANAKA, H. 1995. Medium for quantitative isolation of Pseudomonas solanacearum. Annual of Phytopathological Society of Japan 61: 255 (abstract).

INOUE, Y; NAKAHO, K. 2014. Sensitive quantitative detection of Ralstonia solanacearum in soil by the most probable number-polymerase chain reaction (MPNPCR) method. Applied Microbiology and Biotechnology 98: 4169-4177.

KARGANILLA, AD; BUDDENHAGEN, IW. 1972. Development of a selective medium for Pseudomonas solanacearum. Phytopathology 62: 1373-1376.

KAWANISHI, T; SHIRAISHI, T; OKANO, Y; SUGAWARA, K; HASHIMOTO, M; MAEJIMA, K; KOMATSU, K; KAKIZAWA, S; YAMAJI, Y; HAMAMOTO, H; OSHIMA, K; NAMBA, S. 2011. New detection systems of bacteria using highly selective media designed by SMART: Selective Mediumdesign Algorithm Restricted by Two constraints. PLoSONE 6: e16512.

KELMAN, A. 1954. The relationship of pathogenicity in Pseudomonas solanacearum to colony appearance on a tetrazolium medium. Phytopathology 44: 693-695.

KURYLOWICZ, W. 1981. Antibióticos: uma revisão crítica. Recife: Editora Universitária. $341 \mathrm{p}$.

LEBEAU, A; DAUNAY, MC; FRARY, A; PALLOIX, A; WANG, JF; DINTINGER, J;
CHIROLEU, F; WICKER, E; PRIOR, P. 2011. Bacterial wilt resistance in tomato, pepper, and eggplant: genetic resources respond to diverse strains in the Ralstonia solanacearum species complex. Phytopathology 101: 154-165.

LIN, CH; HSU, ST; TZENG, KC; WANG, JF. 2009. Detection of race 1 strains of Ralstonia solanacearum in field samples in Taiwan using a BIO-PCR method. European Journal of Plant Pathology 124: 75-85.

MARTINELLI, F; SCALENGHE, R; DAVINO, S; PANNO, S; SCUDERI, G; RUISI, P; VILLA, P; STROPPIANA, D; BOSCHETTI, M; GOULART, LR; DAVIS, CE; DANDEKAR, AM. 2014. Advanced methods of plant disease detection: a review. Agronomy for Sustainable Development 35: 1-25.

MORAIS, TP; LOPES, CA; TEBALDI, ND; LUZ, JMQ. 2015. Occurrence and diversity of Ralstonia solanacearum populations in Brazil. Bioscience Journal 31: 1722-1737.

MOURA, A; ROMEIRO, RS. 1998. Meio seletivo para Ralstonia solanacearum baseado na resistência múltipla natural a antibióticos. Fitopatologia Brasileira 23: 466-470.

NESMITH, WC; JENKINS, SF. 1979. A selective medium for the isolation and quantification of Pseudomonas solanacearum from soil. Phytopathology 69: 182-185.

PONTES, NC; KRONKA, AZ; MORAES, MFH; NASCIMENTO, AS; FUJINAWA, MF. 2011. Incorporation of neem leaves into soil to control bacterial wilt of tomato. Journal of Plant Pathology 93: 741-744.

PRADHANANG, PM; ELPHINSTONE, JG; FOX, RTV. 2000. Sensitive detection of Ralstonia solanacearum in soil: a comparison of different detection techniques. Plant Pathology 49: 414-422.

PRADHANANG, PM; MOMOL, MT; OLSON,
SM; JONES, JB. 2003. Effects of plant essential oils on Ralstonia solanacearum population density and bacterial wilt incidence in tomato. Plant Disease 87: 423-427.

PRIOU, S; GUTARRA, L; ALEY, P. 2006. An improved enrichment broth for the sensitive detection of Ralstonia solanacearum (biovars 1 and 2A) in soil using DAS-ELISA. Plant Pathology 55: 36-45.

PRIOU, S; GUTARRA, L; ALEY, P; DE MENDIBURU, F; LLIQUE, R. 2010. Detection of Ralstonia solanacearum (biovar 2A) in stems of symptomless plants before harvest of the potato crop using postenrichment DAS-ELISA. Plant Pathology 59: 59-67.

ROMEIRO, RS; MOURA, A; OLIVEIRA, JR; SILVA, HAS; BARBOSA, LS; SOARES, FMP; PERES, F. 1998. Evidences of constitutive multiple resistance to antibiotics in some plant pathogenic bacteria. Summa Phytopatologica 24: 220-225.

SANTIAGO, TB. 2014. A deep analysis of the genetic structure of Ralstonia solanacearum in Brazil reveals not much sex in the population. Viçosa: UFV. 74p (Tese doutorado).

TAVARES, LA; MICHEREFF, SJ; SOUZA, RM; MARIANO, RLM. 2000. Análise de solo para detecção de risco de infecção de tomateiro por Ralstonia solanacearum. Summa Phytopatologica 26: 311-316.

VAN DER WOLF, JM; VRIEND, SGC; KASTELEIN, P; NIJHUIS, EH; VAN BEKKUM, PJ; VAN, VUURDE JWL. 2000. Immunofluorescence colony-staining (IFC) for detection and quantification of Ralstonia (Pseudomonas solanacearum) biovar 2 (race 3 ) in soil and verification of positive results by PCR and dilution plating. European Journal of Plant Pathology 106: 123-133. 